\title{
Legal forms and ways of application of artificial intelligence technology in making corporate decisions by the board of directors: problems and prospects
}

\author{
Olga Sushkova* \\ Kutafin Moscow State Law University, Moscow, Russia
}

\begin{abstract}
This study investigates the impact of scientific and technological advances and adaptation of artificial intelligence on corporate governance practices. It applies or can be applied in three dimensions - business, technology, and society. Therefore, to assess the necessity, feasibility, effectiveness, and responsibility of decision-making automation at the Board of Directors (supervisory body of a legal entity) to ensure effective corporate governance, it is necessary to consider all normative regulators in the field of corporate law. Based on an assessment of the potential and limitations of human and machine learning for effective decision-making at the level of the collegial governance body, the Board of Directors, the paper proposes five AI-based governance scenarios, i.e., supportive, augmented, enhanced, autonomous, and autopoietic, that can shape the governance of organizations today, tomorrow, and in the future. It is important to understand the implications of such AI-enabled governance in the areas where the Board is empowered to make certain corporate decisions.
\end{abstract}

\section{Introduction}

Although artificial intelligence (AI) is now the focus of many business leaders [1], it is not a new term - it was originally introduced in the 1950s [2]. However, its importance for corporate governance has long been ignored, as in an article by Peter Drucker [3]: "The computer does not make decisions, it only executes commands".

Currently, AI is widely considered a "general purpose technology" [4], and many even view it as a "general solution technology", that is, a solution to any managerial, commercial, or even social problem. In the current state, there is still less attention on the impact of AI on the corporation's vision and management [5]. In this study, we will attempt to analyze the possibilities of using AI in corporate governance practices.

Corporate governance is "the system by which companies are managed and controlled" [6]. The system can be defined as a set of "ownership objects, Boards of Directors activities, incentives, corporate law, and other mechanisms" [7]. Nielson N. J. defines AI as "the activity aimed at creating intelligent machines, and intelligence is the quality that allows an

\footnotetext{
* Corresponding author: ovsushkova@ msal.ru
} 
organization to function properly and visionarily in its environment" [8]. In this regard, our study will focus on the influence of AI on decision-making by the supervisory board, the Board of Directors (BOD), whose activities are related to the control and management of the corporation.

Given the multifaceted nature of corporate governance, we propose an integrated approach that integrates business, i.e., identifying areas of the desirability of applying technology, namely, those areas where corporate decisions need not be analyzed as much or where the Board members need only have a clear understanding of the need, such as when a transaction is based on accounting data or financial analysis.

\section{Study methodology}

General scientific methods of legal phenomena knowledge served as a methodological basis of this work: synthesis, the method of analogy, formal logic and others, and private-scientific methods of research category of artificial intelligence in business, professional and corporate activities. A special place in this study is occupied by the comparative legal method, which proposes implementing AI technologies in Russian corporate practice when making certain types of corporate decisions by the Board of Directors. The integrated approach allowed the formulation of classifications of corporate solutions, which will probably become one of the main criteria for deciding on the effective application of AI in corporate management.

\section{Results of the study}

Business Perspectives on the Application of AI in Board Decision-Making. To better understand the potential contribution of AI to the Board decision-making, we need to elaborate the "structure" of this process [9]. To this end, we will first identify the key functions and typical decisions that, in our view, are most frequently taken by Boards of Directors as collegial governance bodies. Also, it seems important to consider the highest probability and predictability of corporate decisions made by the Board of Directors when using AI.

Classification of decisions of the Board of Directors in foreign jurisdictions. Although national laws of foreign countries differ in terms of the scope of competence and responsibilities assigned to directors, some foreign authors [10] highlight three key roles of Boards of Directors in all jurisdictions: oversight and control functions, joint corporate decision-making (governance) and supervision over execution of such decisions, thus extending the traditional dualistic perspective of governance and control as classical competences of a collegial management body

Joint corporate decision-making (governance). The Board of Directors is responsible for strategic guidance, developing corporate strategy and the top management of the corporation, and ensuring proper implementation of the strategy by setting goals.

Oversight and control functions. Another key responsibility of the Board is to monitor and ensure full compliance with corporate law, Corporate Governance Codes, accounting requirements, and statutory rules of the Company, particularly concerning the Company's finances and risk management. In addition, compliance by shareholders (participants) of business companies and other internal documents (corporate acts) is important.

Overseeing the implementation of corporate decisions. The Board of Directors is also responsible for appointing and overseeing decisions to ensure effective governance.

As we focus on the impact of AI on Board decision-making, we need to identify the key types of decisions that Boards typically deal with (there are other non-standard tasks such as 
crisis management or decisions to approve extraordinary transactions, but these will not be addressed in this study as they are subject to specific rules under corporate law).

Joint corporate decision-making (governance). We see the necessity to propose to systematize such decisions as follows, analyzing most of the decisions made by the Board of Directors within the designated purpose and competencies provided for in the Charter: (a) decision on innovation; (b) decision on cooperation; (c) optimization decision; (d) decision on business restructuring; (e) decision on diversification/concentration; (f) decision on internationalization.

Within the framework of the oversight and control functions that are reflected in the decisions of the Board of Directors, the following classification can be considered: (a) decision on target achievements; (b) decision on compliance with accounting standards; (c) decision on compliance with legislation; (d) decision on compliance with ethical standards.

Finally, when performing the function of supervising the execution of corporate decisions, such decisions can be systematized as follows: (a) decision on executive appointments; (b) decision on executive development; (c) decision on executive compensation; (d) decision on board composition.

To determine which types of decisions benefit most from AI, it is important to be aware of the inherent trait of decision making. Making a decision is always a conscious choice between two or more options. Voting must always be a choice between a positive or negative decision, which can be seen as a technical function entrusted to members of the Board of Directors and an inherent part of their direct responsibilities. The choice always depends on the criteria chosen. A reasoned decision usually follows the same pattern as described in the guidelines [11] (in Russia, this is the Corporate Governance Code - added by the author). Such rules (policies) distinguish between three stages (levels) that usually guide Board members in making corporate decisions: conceptualization, information, and forecasting.

We believe that to appreciate the necessity and importance of using AI technology in decision-making by the collegial management body of a corporation, there is a need to change or confirm the course of action and make a decision. This requires a certain ability to understand the context of the document. Therefore, both legally and technically, it is important to approach the wording of such a document correctly.

Conceptualizing the decision is key to ensuring that all parties involved agree and clearly understand the outcomes that the Board's decision will achieve. However, no corporate decision can be made without properly informing the Board of Directors of the legal implications and the role of the adopted document for the corporation as a whole.

It is necessary to clearly identify the decision options that can be adopted based on the results of a meeting of the collegial management body, assessing the need to use AI technology in corporate decision-making by the Board of Directors. These options should be clearly articulated in light of applicable corporate law and should not be subject to multiple interpretations.

Probability of predictability of decision-making by the Board of Directors. To assess whether it is desirable to use AI in corporate decisions, we propose to apply the etymology of different types of decisions according to a suggestion made by a foreign researcher back in 1992 (it should be emphasized that corporate laws in Russia have been adopted only since 1995 - added by the author) [12]. The scholar proposes four types of decisions depending on the degree of certainty and agreement of the members of the collegial body:

Common decisions: Some decisions are considered fairly straightforward because the outcome is obvious, and all decision-makers are in full agreement with them.

Complex solutions (first level). They can include such substantive solutions, the result of which depends on several optional elements (events or actions), the occurrence or nonoccurrence of which will give the corporation the result on which it counted (for example, when using the options structure in a business transaction, i.e., the occurrence of the event 
conditional - added by the author). Therefore, when discussing such a decision, different assumptions and statements may be made by members of the Board of Directors, which may affect the overall outcome of the meeting's agenda.

Complex solutions (second type). Decisions of this type are made in a context that is either completely uncertain or leads to significant disagreement.

Chaotic solutions. These are decisions made in a volatile environment (for example, in an economic crisis to which many countries, including Russia, are subject - added author). Thus, when such decisions are debated, the outcome may not be predictable at all.

How can this logic be applied to decision-making using AI technology at the Board level? This is the question that forms the basis of this study.

Corporate Governance in Russia. Corporate governance in Russia is defined in both doctrine and legislation. Shitkina I.S. believes that "corporate governance is a set of ways of influence or a process by which the activities of corporations are organized. The Board of Directors (Supervisory Board) is a collegial management body of a business company, performing the general management of its activities, elected at the general meeting of shareholders (participants) [13]. At the same time, the existing Corporate Governance Code, which defines the principles of corporate governance, provides the procedure and conditions for applying such principles [14]. In Russian law, the influence of corporate governance principles on the activities of business entities is powerful. Since the mentioned Code considers the Russian realities and has a more applied nature than the earlier Corporate Governance Code (2002) [15]. In addition, the Code is focused on PJSCs, JSCs, and, to some extent, LLCs. Regarding the application of the Code to the activities of the Board of Directors, the text focuses on building its effective work (defining the approaches to reasonable and bona fide performance of duties by members of the Board of Directors, defining its functions, organization of its work and committee). The Code also clarifies the requirements for directors, including independent directors.

The competence of the Board of Directors is the control over the activities of the executive bodies of the Corporation and performance of other functions, which are assigned to it by the Charter or the law (Clause 4 of Article 65.3 of the Civil Code of the Russian Federation) [16]. It should be noted that the legislation does not contain a universal list of powers vested in the Board of Directors. For example, Article 65 of the Federal Law "On Joint Stock Companies" [17] defines the competence of the Board of Directors. However, it should be remembered that such a governing body is mandatory only for PJSCs. As for non-public business entities (JSC and LLC), the formation of the Board of Directors is not mandatory. I.S. Shitkina suggests the following classification of the Board of Director's competencies. We emphasize that such classification is necessary when a company chooses to use AI technology in decision-making, which, in our opinion, will simplify corporate governance procedures without affecting the rights and legitimate interests of shareholders or LLC participants.

It should be noted that even today in the RF, there is a legal possibility to hold a general meeting of shareholders using electronic ballots (Art. 58 of the Law on JSC) [18]. In our opinion, the application of this norm in practice is positively characterized. Osipenko O.V. believes [19] that when making a decision, for example, on the choice of members of the Board of Directors and their personal selection, there may be a liability for error (in the case when the ballot is filled out by a shareholder who is present in person at the meeting). If such an "electronic bulletin" is filled out in advance, taking into account the specialist's explanations, negative consequences for such shareholders are more likely not to occur. He will not be held liable, including given the constituent elements provided for by the Code of Administrative Offences of the Russian Federation.

We think that shortly, the legislator will consider the possibility, if indicated in the Articles of Association of a business company, to apply new technologies, such as AI, when 
making "technical decisions" by the Board of Directors, taking into account its special function in the system of management bodies of the Company.

\section{Discussion of the results}

I.S. Shitkina distinguishes: relative exclusive and additional exclusive competence of the Board of Directors. The relative exclusive competence of the Board of Directors refers to those issues that the JSC Law defines as the exclusive competence of the Board of Directors, provided that it is referred to its competence by the charter of the company or, conversely, the charter of the company does not otherwise establish it. The matters of relative competence of the Board of Directors of a joint stock company include, for example, increase of the charter capital of the company by placing additional shares within the limits of the declared shares, placement by the company of bonds and other issue-grade securities, formation of the executive body, early termination of its powers. In this connection, it can be said that AI technologies can be applied to the "technical" powers of the Board of Directors, should such a decision need to be taken. We are of the same opinion regarding the application of AI technology, referring to the additional exclusive competence of the Board of Directors, which consists of the issues, referred to the Board of Directors by the Charter of the Company, as the legislation provides for such possibility (subpara. 18 p. 1 art. 65 of the JSC Law). The Civil Code and the JSC Law give the shareholders themselves the right to extend the Board of Directors' competence beyond the list contained in Article 65 (1) of the JSC Law. Issues of additional competence are always the result of the joint-stock company's own discretion [20].

It is necessary to separately identify the problem of classification of corporate acts of the corporation. Since a number of them are adopted by the Board of Directors, as stipulated by the corporate laws but, these decisions (corporate acts) should be systematized along with others, which are adopted, for example, by the supreme governing body - the general meeting of participants (shareholders).

As noted by I. S. Shitkina, "...in modern legal science essentially, there is no systemic research of local normative activity of business entities [21] ... points of view of domestic legal scholars often differ in the issues of determining the essence, place, and role of local normative acts, their hierarchy in the structure of legal regulation" [22].

S.D. Mogilevsky notes that the formation of will and expression of the will of a legal person always need some final registration, and as the final registration of this will the legal act of a legal person acts [23] - "based on the law and other legal acts will or expression of the will of a legal person, developed and drawn up in an established procedure in the form of a special act of a legal person and aimed at establishing local legal rules or the occurrence, change and termination of civil law relations, the formation of the will and expression of the will of a legal person [25]. Leskova Y.G. concludes that "the above definition may well be applicable to the legal acts of any legal entity, including corporations. However, from the very name "corporate legal act," it should be assumed that its definition and characteristic should contain the features peculiar to the legal act as a corporate one. The nature of a corporate act seems to be similar to that of a legal act" [25].

\section{Conclusions}

Nowadays, big business entities (corporations) are increasingly trying to incorporate digital technologies into their corporate practices. Due to the fact that the number of corporate solutions consistently increases, branches or other structural units of the corporation are opening more and more, increasing the scale of doing business, such business entities face 
the issue of its optimization. Therefore, recognizing the strategic value of information and corporate data, AI technology itself becomes, in some cases, a valuable corporate asset of a legal entity. Its role rises, and the value of the corporation's intangible assets also increases significantly. Consequently, the management of these key assets is of strategic importance and should be decided at the Board level. At the same time, data issues pose serious risks and, increasingly, are shaping corporate culture and the relationship between companies and society. At the same time, the Board needs to be aware that AI affects the business and the Board itself, i.e., AI-enabled governance. This awareness is necessary for the Board to be more data-driven. Since no single organization will be able to develop or use such algorithms in isolation to realize their full potential, the collaboration between organizations in ecosystems will be critical. This leads to some legal issues, such as liability for the algorithm, i.e., if those who use or build it are liable for its outcome, i.e., whether a better algorithm can lead to bad behavior. As the technological capabilities of organizations to influence human thought will be broader and more difficult to control, their regulation will be highly controversial but also influential. At the same time, organizations are likely to become selforganizing systems in the literal sense of the word; that is, they will operate without any human intervention. While the business appetite for AI is clear and the technological advances are evident, in the end, the social dialogue will be critical. In this regard, companies will have to prove that they are aware of their responsibility regarding AI to gain public trust. At the same time, AI will profoundly impact corporate governance by enabling a range of new governance mechanisms and systems. The result could be a refined concept of limited liability companies and the capital market.

\section{References}

1. T. H. Davenport, R. Ronanki, Artifcial intelligence for the real world. Massachusetts. Harvard Business Review, 134 (2018)

2. S. J. Russell, P. Norvig, Artifcial intelligence: a modern approach (3rd ed.). Upper Saddle River: Prentice Hall, 334 (2016)

3. P. F. Drucker, McKinsey Quarterly 3(4), 42 (1967)

4. J. B. Mantas, Intelligent approaches to AI. Directorship, 40 (2019)

5. B. Libert, M. Beck, M. Iansiti, K. R. Lakhani, Competing in the age of AI. Boston: Harvard Business Review Press, 334 (2020)

6. A. Cadbuy, Code of best practice: report of the committee on the fnancial aspects of corporate governance, 15 (London: Gee and Co., 1992)

7. S. Thomsen, An introduction to corporate governance: mechanisms and systems, 15 (Copenhagen, Djof Publishing, 2008)

8. N. J. Nilsson, The quest for artifcial intelligence - a history of ideas and achievements, 13 (Cambridge: Cambridge University Press, 2010)

9. O.V. Sushkova, Legal regulation of artificial intelligence: problems of correlation and application in business and corporate law. In the book: The rights and obligations of a citizen and public authorities, the search for a balance of interests of the XVII International-scientific-practical. confer. (Kutafin readings) of the Kutafin Moscow state Law University (MSAL) and XX Int. scientific-practical confer. jurid. Faculty of the Lomonosov Moscow State University : at 5 part, Part VI: M .: Prospect, 421 (2020)

10. D. Cossin, E. Metayer, How strategic is your board? Cambridge: MIT Sloan Business Review, 436 (2014) 
11. R. R. Still, E.W. Cundif, N. A. Govoni, Sales management: decisions, policies, and cases. Englewood Clifs: Prentice-Hall, 325 (1958)

12. R. Stacey, Managing the unknowable: the strategic boundaries between order and chaos, 248 (London, Jossey-Bass, 1992)

13. A.V. Gabov, E.P. Gubin, S.A. Karelina et al., Corporate law: textbook otv. ed. I.S. Shitkina, 270 (Moscow: Statut, 2019)

14. Bank of Russia Letter No. 06-52 / 2463 of April 10, 2014 "On the Corporate Governance Code", Bank of Russia Bulletin 40, April 18, 2014.

15. Order of the Federal Commission for the Securities Market of the Russian Federation of 04.04.2002 N 421 / r "On Recommendations for the Application of the Code of Corporate Conduct" (together with the "Code of Corporate Conduct" dated 05.04.2002), Bulletin of the Federal Commission for the Securities Market of Russia. No. 4. 30.04.2002 (order) (the document is no longer valid)

16. The Civil Code of the Russian Federation (part one) dated 30.11.1994 No. 51-FZ (as amended on 09.03.2021). Collection of legislation of the Russian Federation. 1994. No. 32. Art. 3301.

17. Federal Law of December 26, 1995 No. 208-FZ (as amended on July 31, 2020, as amended on February 24, 2021) "On Joint Stock Companies" (as amended and supplemented, entered into force on 01.01.2021) // Collection of legislation of the Russian Federation. 1996. N 1. Art. 1

18. Bank of Russia Regulation No. 660-P dated November 16, 2018 "On General Meetings of Shareholders" (Registered with the Ministry of Justice of Russia on January 9, 2019 No. 53262), Bank of Russia Bulletin 3, January 22, 2019.

19. O.V. Osipenko, Actual Problems of Systemic Application of Corporate Governance and Joint Stock Law Tools, 174 (Moscow, Statut, 2018)

20. E.G. Afanasyeva, V.A. Vaypan, A.V. Gabov et al., Corporate Law: training course: in 2 volumes. ed. I.S. Shitkina, T 2, 105 (Moscow, Statut, 2018)

21. A.V. Mikhaylov, General questions of the effectiveness of legal regulation of entrepreneurial relations. Modern problems of legal science and law enforcement practice: Sat. scientific. tr. Under total. ed. O. A. Zayachkovsky. Kaliningrad: IKBFU Kant Publishing House, 75 (2018)

22. I.S. Shitkina, State and Law 10, 100 (1999).

23. S. D. Mogilevsky, Management bodies of business companies: Dis. ... doct. jurid. sciences. M., 120 (2001)

24. S. D. Mogilevsky, Limited Liability Company: legislation and practice of its application, M., 245 (2010)

25. Yu.G. Leskova, Philosophy of Social Communication 3(20), 44 (2012) 